\title{
THE DISTRIBUTION OF PATHOGENS, RISK FACTORS AND THEIR ANTIMICROBIAL SUSCEPTIBILITY PATTERNS AMONG POST-SURGICAL SITE INFECTION IN RIZGARI TEACHING HOSPITAL IN ERBIL/KURDISTAN REGION/IRAQ
}

\author{
Haval Hassan Abdulqader ${ }^{*}$ and Abdulrahman Towfeeq SaAdi ${ }^{* *}$ \\ *Rizgari Teaching Hospital/Erbil City, Kurdistan Region-Iraq \\ *** Dept. of Microbiology, College of Medicine, University of Duhok, Kurdistan Region-Iraq
}

(Received: June 24, 2018 ; Accepted for Publication: April 15, 2019)

\begin{abstract}
Objectives: to find out the incidence of Post-Surgical Site Infections, risk factors, types of the isolated bacteria and their antibiotic susceptibility patterns for patients admitted to Rizgari Teaching Hospital in Erbil city.

Methods: A prospective study was performed on 160 patients admitted to Rizgary Teaching Hospital for surgical operations over a period of six months (November 2015 to June 2016). Culture, identification and sensitivity tests for the isolated organisms from Post-Surgical Site Infections were done by using VITEK 2 systems in Laboratory of Rizgari Hospital.

Results: The incidence of PSSIs was 19.4\% . E.coli was the most common isolated pathogen (29.2\%) followed by Staphylococcus aureus (20.8\%). Both Klebsiella pneumonia and Coagulase Negative Staphylococcus had $12.5 \%$ for each. Pseudomonas aeruginosa and Enterococcus faecium had $8.3 \%$ each and both Acinetobacter baumannii and Streptococcus spp. had only $4.2 \%$ each There was $100 \%$ resistance of $E$. coli regarding third generation cephalosporin but were $100 \%$ sensitive to Imipenem and meropenem. $60 \%$ of Staphylococcus aureus were resistant to oxacillin (MRSA). Smoking, past medical history, contaminated wounds, long duration of operation, and improper use of antibiotics were risk factors.

Conclusion: There was an increased rate of PSSIs due to risk factors. There were multi-resistant strains of isolated bacteria mainly E.coli and Staphylococcus aureus which denotes the abuse of antibiotics. This can be attributed to lack of proper guidance for the use of antibiotics both prophylactically and postoperatively.
\end{abstract}

Keywords: Post-Surgical Site Infections, Hospital Acquired Infections, E. coli and S. aureus.

\section{INTRODUCTION}

$\mathbf{P}$ ost-surgical wound infections are a common cause of Nosocomial Infections world-wide, accounting for $38 \%$ of nosocomial infections in USA where it is estimated to affect 2$5 \%$ of patients undergoing surgical operations ${ }^{1}$.

The United States Centre for Disease Control and Prevention (CDC) has defined Post Surgical Infections (PSSIs) as infection caused by an operative procedure at surgical incision within 30 days of the procedure or within 90 days if prosthetic material is implanted at operation. Although advances have been made in infection control practices, including improved theatre ventilation, sterilization methods, and proper use of antimicrobial prophylaxis, PSSIs remain a leading cause of morbidity, prolonged admission, and death. PSSI is associated with a mortality rate of $3 \%^{2,3}$

Risk factors of developing PSSIs include the level of microbial contamination, age of the patients, duration of surgery and the presence of diabetes mellitus and obesity ${ }^{4}$. Many studies have shown the majority of bacteria causing PSSIs to be $S$. aureus and among gram negative bacilli: $E$. coli, Klebsiella and Pseudomonas. They may include anaerobic bacteria ${ }^{6}$. There is an increase in incidence of PSSIs caused by antimicrobial resistant bacteria such as Methicillin Resistant Staphylococcus aureus (MRSA) and Vancomycin Resistant Staphylococcus aureus (VRSA) ${ }^{7}$. 
An infected wound can prolong hospitalization by many days and subsequently increase medical $\operatorname{costs}^{8}$. The English Nosocomial Infection National Surveillance Scheme (NINSS) has stated that the overall incidence of PSSIs was $4.3 \%$ of all surgical operations, of which a quarter were serious deep or organ infections ${ }^{9}$.

Indications for antibiotic prophylaxis are contaminated and clean-contaminated surgery and operations involving artificial device and prosthetic material. To lesser extent are clean operations in patients with lack of immunity or patients in who involved in big operation as in ophthalmic surgery, open heart surgery and neurosurgery ${ }^{10}$.

\section{METHODS}

The study was performed at the Rizgary Teaching Hospital in Erbil/Iraq, a government teaching hospital which performs minor to major operations. A prospective study was performed on patients (160) admitted to Rizgary Teaching Hospital in Erbil. Most of the operations were elective. Data were collected over a period of six months between November 2015 to June 2016 from patients underwent surgeries. Data from each patient were collected according to a flow chart questionnaire developed for this purpose. These included name, age, duration of hospital stay, type of operation, and past medical history.

The incidence of PSSIs was estimated for each type of surgery and 30 days follow up since the day of the operation. The patients were postoperatively followed up in the Outpatient Department postoperatively and some of them were followed up by telephone interview for any signs and symptoms of infection. Also surveillance cards were given to the patients for feedback information. In addition notes written by some surgeons during the patients visits to the clinics were also considered. The data recorded included date of admission, date of discharge, wound classification and comorbidities.

In patients who developed one of the clinical signs, a wound swab was obtained and sent to the Microbiology section for bacterial identification and for antibiotic sensitivity tests. Swabs were cultured on three plates: MacConkey agar, Blood agar, and Chocolate agar and incubated at $37^{\circ} \mathrm{C}$ for 24-48 hours according to the standard bacteriological method ${ }^{11}$. After incubation, identification of bacteria from positive cultures was done which included studying the colonial morphology, Gram stain and biochemical reactions (catalase and coagulase tests for gram positive bacteria and oxidase test for gram negative bacteria). Further confirmation of the types of the bacteria and the antibiotic sensitivity pattern of all the isolates were performed using VITEK 2 systems.

The statistical package for social sciences (SPSS) version 19 software was used for data analysis. The 2-tailed chi-squire test and Fisher exact test were used for categorical variables. Chisquare test and Student's t-test were used for continuous variables for the univariate comparison. A two-tailed $\mathrm{P}<0.005$ was considered as statistically significa

\section{RESULTS}

The study sample was 160 patients, 58 males (36.2\%) and 102 patients females (63.8\%); the male to female ratio was 1:1.7 Among the 31 cases of PSSIs, there were 20 males $(64.5 \%)$ and 11 females $(35.5 \%)$. This relation between gender and PSSIs was statistically significant $(\mathrm{P}$ value $=<$ $0.001)$.

The distribution of number of PSSIs among various age groups is shown in Table 1 .

Table (1): Age groups and number of PSSIs.

\begin{tabular}{llll}
\hline Age group (Years) & Number of patients & Number and percentages of PSSIs & PSSI not present \\
\hline $11-25$ & 25 & $4(16 \%)$ & $21(84.0 \%)$ \\
\hline $26-40$ & 70 & $14(20 \%)$ & $56(80 \%)$ \\
\hline $41-55$ & 45 & $7(15.6 \%)$ & $38(84.4 \%)$ \\
\hline $56-80$ & 20 & $6(30 \%)$ & $14(70 \%)$ \\
\hline
\end{tabular}

There were 31 patients were having PSSI with an incidence rate of $19.4 \%$. There were 20 cases of PSSIs with culture positive microorganisms
(64.5\%). There were 6 cases of PSSIs (19.3\%) among the total positive cases diagnosed according to clinical signs and symptoms but of 
culture negative. In addition, there were 5 cases (16.2\%), of PSSI diagnosed on basis of the surgeon's decision.
Table 2 shows that duration of the operation has direct effect on the occurrence of PSSIs and it was statistically significant $(\mathrm{P}$ value $=<0.001)$.

Table (2): Effects of duration of operation on the number of PSSIs.

\begin{tabular}{llll}
\hline Duration of operation & Number of patients & Number of PSSIs & P values $=\mathbf{0 . 0 0 1}$ \\
\hline$<60 \mathrm{~min}$ & 110 & $13(11.8 \%)$ \\
\hline$<90 \mathrm{~min}$ & 37 & $13(35.1 \%)$ \\
\hline$<120 \mathrm{~min}$ & 9 & $03(33.3 \%)$ \\
\hline$>120 \mathrm{~min}$ & 4 & $02(50 \%)$ \\
\hline
\end{tabular}

The day of admission has a direct effect on PSSIs, which was statistically significant (P value $=<0.001)$ as shown in table 3 .

Table (3): Number of PSSIs in relation of days of stay in hospital.

\begin{tabular}{|c|c|c|c|}
\hline Days at hospital & Number of patients & No. and $\%$ of PSSIs & $P$ value $=<0.001$ \\
\hline For 1 day & 109 & $10(9.2)$ & \\
\hline 2days & 36 & $15(41.7)$ & \\
\hline$>2$ days & 15 & $6(40.0 \%)$ & \\
\hline
\end{tabular}

Regarding WBCs count, Blood sugar levels and BMI among the patients; both WBCs count and BMI had statistically significant association
$\mathrm{P}<0.001$ for PSSIs. However there was no statistically significant association with blood sugar.

Table (4): shows the effect of duration of antibiotic

\begin{tabular}{|c|c|c|c|}
\hline Duration of $A B$ prophylaxis & Number of patients & No and $\%$ of PSSIs & $\begin{array}{l}P \text { value }= \\
<0.001\end{array}$ \\
\hline 1 Antibiotic for 1 week & 85 & $20(23.5 \%)$ & \\
\hline 2 Antibiotics for $>10$ days & 10 & $7(70 \%)$ & \\
\hline 2 Antibiotics for 1 week & 14 & $4(28.6 \%)$ & \\
\hline $1 \mathrm{~h}$ before operation & 24 & 0 & \\
\hline No antibiotics & 27 & 0 & \\
\hline
\end{tabular}


prophylaxis on the occurrence of PSSIs. There were no PSSIs in those patients who received antibiotic $1 \mathrm{~h}$ before the operations compared to use of antibiotics 1 week and 10 days postoperatively. This was statistically significant $(\mathrm{P}$ value $=<0.001)$.

e 4 Effects of antibiotic prophylaxis on number of PSSIs
According to Southampton wound classification, 110 patients had clean wounds, 36 patients had clean-contaminated wounds, and 14 patients had contaminated wound. PSSIs was highest among the contaminated operations, and this was statistically highly significant $(\mathrm{P}$ value $=$ $<$

$0.001)$.

Table (5): Number of PSSIs regarding types of wounds.

\begin{tabular}{llll}
\hline Types of wounds & Number of patients & Number and $\%$ of SSIs & P value $=<\mathbf{0 . 0 0 1}$ \\
\hline Clean wounds & 110 & $9(8.2 \%)$ & \\
\hline Clean contaminated & 36 & $10(27.8 \%)$ \\
\hline Contaminated & 14 & $12(85.7 \%)$ \\
\hline
\end{tabular}

Table (6): Frequencies and percentages of pathogens isolated from PSSIs.

\begin{tabular}{|c|c|c|c|}
\hline & & Frequency & Percentage \\
\hline \multirow{4}{*}{ Gram Negative } & E.coli & 7 & $29.2 \%$ \\
\hline & Pseudomonas aeruginosa & 2 & $08.3 \%$ \\
\hline & Klebsiella pneumoniae & 3 & $12.5 \%$ \\
\hline & Acinetobacter baumannii & 1 & $04.2 \%$ \\
\hline \multirow{4}{*}{ Gram Positive } & Staphylococcus aureus & 5 & $20.8 \%$ \\
\hline & Streptococcus spp. & 1 & $04.2 \%$ \\
\hline & CON Staphylococcus & 3 & $12.5 \%$ \\
\hline & Enterococcus facium & 2 & $08.3 \%$ \\
\hline
\end{tabular}

A total of 24 positive cultures were obtained from a total of 26 swabs, taken from clinically infected wounds. Single pathogens were isolated from $(69 \%)$ of these swabs; while $(8 \%)$ culture results grew mixed pathogens. In 6 of the culture results $(23 \%)$, there were no pathogens isolated.

Escherichia coli were the most common species isolated from the cultures (table 6), accounting for 7 isolates $(29.2 \%)$ of the total organisms isolated from the PSSIs. Staphylococcus aureus accounted for 5 isolates (20.8\%) and both Klebsiella species and CON Staphylococcus had 3 strains (12.5\%) while both Pseudomonas aeruginosa and Enterococcus faecium had 2 isolates (8.3\%) each. Lastly, both Acinetobacter baumannii and Streptococcus spp. had only one positive strain $(4.2 \%)$ for each.

The antibiotic resistant rate for E. coli (7 isolates) was $100 \%$ for Ampicillin,Augmentin, Piperacillin, Ticarcillin,Levofloxacin, Cefazolin, Ceftazidime, Ceftriaxone, Cefepime and Aztreonam. $85.5 \%$ resistance for Ciprofloxacin, $57 \%$ for Gentamicin, $50 \%$ Colistin, $29 \%$ Tazocin, Nitrofurantoin and Trimethoprim Sulfa and 14\% for Amikacin. However the resistance was $0 \%$ for Imipeneme, Meropenem and Tigecyclin. This pattern was almost the same for the 2 isolates of Klebsiella

pneumonia. 
Table (7): Frequencies (No.) and percentages of antibiotic resistance (R)

\begin{tabular}{|c|c|c|c|c|}
\hline \multirow[t]{2}{*}{ Antibiotic } & \multicolumn{4}{|c|}{ Antibiotic Resistant } \\
\hline & $\begin{array}{c}\text { E.coli } \\
\text { No. and } \mathrm{R}(\%)\end{array}$ & $\begin{array}{c}\text { Staphylococcus } \\
\text { aureus } \\
\text { No. and R (\%) }\end{array}$ & $\begin{array}{c}\text { Klebseilla } \\
\text { pneumonia } \\
\text { No. and R (\%) } \\
\end{array}$ & $\begin{array}{c}\text { CON staphylococcus } \\
\text { No. and R (\%) }\end{array}$ \\
\hline Benzylpencillin & & $0 / 5(0 \%)$ & & $0 / 2(0 \%)$ \\
\hline Gentamicin & $4 / 7(57.1 \%)$ & $1 / 5(20 \%)$ & $2 / 2(100.0 \%)$ & $0 / 2(0.00 \%)$ \\
\hline Tobramycin & $4 / 7(57.1 \%)$ & $2 / 5(40.0 \%)$ & $2 / 2(100.0 \%)$ & $0 / 2(0.00 \%)$ \\
\hline Ciprofluxacin & $6 / 7(85.8 \%)$ & $1 / 5(20.0 \%)$ & $0 / 2(0.00 \%)$ & $0 / 2(0.00 \%)$ \\
\hline Erythromycin & & $1 / 5(20.0 \%)$ & & $2 / 2(100.0 \%)$ \\
\hline Levofluxacin & $6 / 7(85.8 \%)$ & $1 / 5(20.0 \%)$ & $0 / 2(0.00 \%)$ & $0 / 2(0.00 \%)$ \\
\hline Moxifluxacin & $6 / 7(85.8 \%)$ & $0 / 5(0.00 \%)$ & $0 / 2(0.00 \%)$ & $0 / 2(0.00 \%)$ \\
\hline Clindamycin & & $3 / 5(60.0 \%)$ & & $2 / 2(100.0 \%)$ \\
\hline Linezolid & & $0 / 5(0.00 \%)$ & & $0 / 2(0.00 \%)$ \\
\hline Teicoplanin & & $1 / 5(20.0 \%)$ & & $2 / 2(100.0 \%)$ \\
\hline Vancomycin & & $3 / 5(60.0 \%)$ & & $2 / 2(100.0 \%)$ \\
\hline Tetracyclin & & $1 / 5(20.0 \%)$ & & $0 / 2(0.00 \%)$ \\
\hline Tigecyclin & & $0 / 5(0.00 \%)$ & & $0 / 5(0.00 \%)$ \\
\hline Nitrofurantion & $1 / 7(14.2 \%)$ & $0 / 5(0.00 \%)$ & $1 / 2(50.0 \%)$ & $0 / 2(0.00 \%)$ \\
\hline Fucidicacid & & $1 / 5(20.0 \%)$ & & $0 / 2(0.00 \%)$ \\
\hline Fosmomycine & & $0 / 5(0.00 \%)$ & & $0 / 2(0.00 \%)$ \\
\hline Rifampicin & & $2 / 5(40.0 \%)$ & & $0 / 2(0.00 \%)$ \\
\hline Trimethioprim_Sulfa & $4 / 7(57.1 \%)$ & $1 / 5(20.0 \%)$ & $2 / 2(100.0 \%)$ & $0 / 2(0.00 \%)$ \\
\hline Oxacillin & & $3 / 5(60.0 \%)$ & & $0 / 2(0.00 \%)$ \\
\hline Piparcillin/tazobactam & $4 / 7(57.1 \%)$ & & $0 / 2(0.00 \%)$ & \\
\hline Amikacin & $1 / 7(14.2 \%)$ & & $0 / 2(0.00 \%)$ & \\
\hline Ertapenem & $0 / 7(0.00 \%)$ & & $0 / 2(0.00 \%)$ & \\
\hline Imepenem & $0 / 7(0.00 \%)$ & & $0 / 2(0.00 \%)$ & \\
\hline Meropenem & $0 / 7(0.00 \%)$ & & $0 / 2(0.00 \%)$ & \\
\hline Ampicillin & $4 / 4(100.0 \%)$ & & $0 / 2(0.00 \%)$ & \\
\hline Amoxillin_Clavulanic & $4 / 4(100.0 \%)$ & & $0 / 2(0.00 \%)$ & \\
\hline Ampicillin Sulbactam & $4 / 5(80.0 \%)$ & & $0 / 2(0.00 \%)$ & \\
\hline Piperacillin & $4 / 4(100.0 \%)$ & & $0 / 2(0.00 \%)$ & \\
\hline Colistin & $2 / 2(50.0 \%)$ & & $0 / 2(0.00 \%)$ & \\
\hline Ticarcillin & $4 / 4(100.0 \%)$ & & $0 / 2(0.00 \%)$ & \\
\hline Ticarcillin Clavulanate & $4 / 4(100.0 \%)$ & & $0 / 2(0.00 \%)$ & \\
\hline Cefazolin & $4 / 4(100.0 \%)$ & & $0 / 2(0.00 \%)$ & \\
\hline Ceftazidime & $5 / 5(100.0 \%)$ & & $0 / 2(0.00 \%)$ & \\
\hline Ceftriaxone & $5 / 5(100.0 \%)$ & & $0 / 2(0.00 \%)$ & \\
\hline Cefepim & $5 / 5(100.0 \%)$ & & $0 / 2(0.00 \%)$ & \\
\hline Aztreonam & $5 / 5(100.0 \%)$ & & $0 / 2(0.00 \%)$ & \\
\hline
\end{tabular}

For $S$. aureus (5 isolates) rate of resistance was $100 \%$ for Levofluxacin, Tigecycline, Nitrofurantoin, Linezolid and Fucidic acid. 20\% was for Gentamicine, Ciprofluxacin, Erythromycin, Teichoplanin, Tetracyclin and Trimethoprim sulfa. Was $40 \%$ for Tobramycin and Rifampicin. It was $60 \%$ Clindamycin, Vancomycin and oxacillin.
The two isolated strains of Pseudomonous spp. were sensitive Levofloxacin, Ciprofloxacin, Amikacin, Ampicillin Sulbactam, Linezolid, Vancomycin, Piperacillin-Tazobactam, Ceftazidime,Cefepime, Ceftriaxone, Imepenem, Meropenem, Gentamycin, Tobramycin; however, they were only Resistant to Trimethoprime-Sulfa (Table 7).DISCUSSION//////This study showed that male to female ratio was $1: 1.7$ which is in 
agreement with other studies done in Iraq and in Iran ${ }^{12,13}$. However, the ratio was contradictory to another study done in Saudi Arabia ${ }^{14}$. Regarding PSSIs, there were 20 males and 11 females among the total 31 cases of PSSIs and it was statistically significant $(\mathrm{P}$ value $=<0.001)$. The explanation for gender differences in PSSIs incidence rate resides in the differences between women and men's skin biology. Besides, the thicker and coarser male hair might cause a higher risk of infection ${ }^{14} . / / / / / / /$ The highest number of admitted patients (70) was among the age group (26-40) years and only 20 patients at age group (56-80) years (Table 1). This is similar to results of a study done in Saudi Arabia ${ }^{15}$. A study done in Egypt ${ }^{16}$ showed the highest number of patients was in the age group 41-65 years.

Among the total number of PSSIs (31), the highest percentage of PSSIs (30\%) was among ages $>56$ (Table 1). This was statistically nonsignificant compared to other age groups ( $P$ value $=0.559$ ). Several earlier studies also indicated PSSIs rates were the highest among elderly patients $15,16,17,18,19$. The differences between the various age groups and PSSIs may be due to the types and selection of the patients and operations in each study.

The incidence of PSSIs in this research was high (19.4\%) which is nearly similar to the incidence rate $\operatorname{Iran}^{13}$ and Egypt $^{16}$. Also, the incidence of African countries (from 1995-2010) shows $12 \%, 19 \%$, and $16-31 \%$ for Algeria, Kenya, and Nigeria respectively ${ }^{20}$. This incidence rate is higher than the average of $11.8 \%$ in developing countries $^{19}$ and much higher than those for developed countries, as the incidence rates were $1.9 \%$ in the United States, $1.6 \%$ in Germany, $1.4 \%$ in England, $1.6 \%$ in France and $2.0 \%$ in Portugal ${ }^{19}$. In another study the cumulative incidence of PSSIs ranged from $10.0 \%$ to $30.9 \%$ in low income countries. But the rate was $2.6 \%$ in the United States, and 3\% in different European countries ${ }^{19}$.

The potential factors contributing to the high rate in this study may be attributed to the limited resources and powers allocated to infection control measures. There were no documented guidelines for safer surgery and proper antibiotic prophylaxis to prevent PSSIs. In addition, implementing post discharge surveillance was difficult because patients usually do not return to hospital for follow up and may return to private clinics or paramedics. In addition telephone follow up has high specificity but low sensitivity. The surgeon's decision for follow up also has limited data and low specificity and sensitivity, because most surgeons are reluctant to give real incidence of PSSIs.

Regarding wound classification, the highest number of patients admitted to Rizgary Teaching Hospital was due to clean wound followed by clean-contaminated and the least were contaminated wounds. The infection rate was highest for contaminated wounds $(64.2 \%)$ which is statistically highly significant ( $\mathrm{P}$ value $=<$ 0.001). These results were higher than the acceptable reported rates. In a study done in Pakistan, the percentages were $5.4 \%, 11.4 \%$, and $20.0 \%$ respectively $^{21}$, which are also a much higher than those percentages obtained in another study done in Iraq, whereby the rates were 3\%, $6.25 \%$, and $11 \%$ for clean, clean-contaminated, and contaminated wounds respectively ${ }^{6}$. This high percentages of PSSIs among contaminated wounds can be attributed first to abuse of antibiotic prophylaxis; second to the lengthy time of surgical operations, obesity, presence of past medical history, lack of infection control guidance and low nurse-to-patient ratio.

This research indicated that smoking had a significant association with PSSIs. Similar results were shown by other studies ${ }^{12,13,15,17}$. In addition past medical history (PMH) also had significant association with PSSIs, in particular hypertension. Other studies done in Iran ${ }^{13}$ Pakistan $^{21}$ and Egypt $^{16}$ also have shown similar outcome. Among other risk factors for PSSIs were wound contamination, duration of surgery and antibiotic prophylaxis. These results were consistent with other studies from other countries ${ }^{27,28,29,30}$. There was no statistical significant between high level of blood sugar and PSSIs. This may be due to good control of diabetes preoperatively which reduce the rate of PSSI. Other studies have shown an association between diabetes and PSSIs ${ }^{15}$ and the percentages of surgical patients with diabetes could be higher, depending on the type of surgery performed $^{26}$. There were 19 PSSIs among the patients with BMI $>24.9 \mathrm{~kg} / \mathrm{m} 2$ out of 77 with $24.67 \%$ compared to $14.5 \%$ among patients with BMI $<24.9$ and this was statistically significant, as studies have shown similar results $22,23,24,25,27$.

WBCs $>11,000$ had $90 \%$ association with PSSIs compared to $18.2 \%$ association with WBCs $<11,000$ and this was statistically significant. White blood cell counts in recently spinal surgery 
could be a predictor for complications postoperation $^{27}$.

There was a statistically significant correlation between duration of operation and PSSIs (Table 4). It was $50 \%$ for operations lasted for $>2$ hours which was the highest compared to $<1 \mathrm{~h}$. Studies done in Iraq, Iran, Saudi Arabia, Egypt, and developed countries had similar patterns ${ }^{13,15,16}$.

Regarding the duration of hospital stay, there were higher numbers of PSSIs for patients staying for $>48$ hours in hospital compared to stay for < 48 hours and this was statistically significant $\mathrm{P}$ $=<0.001$. This is in agreement with other studies $12,13,15,19,33$

Antibiotic prophylaxis had a highly statistically significant number of PSSIs when antibiotics were used for 1-2 weeks postoperatively compared to one dose of antibiotics given prophylactically one hour before induction of anaesthesia and also compared to those not given antibiotics at all in clean-wound operations. In a study carried out in Rizgary Teaching Hospital, it was found that intra-medication administration (within 1 hour before, and 24 hours after a surgical procedure) still accounts for a lower proportion of PSSIs relative to post-medication ${ }^{28}$

The appropriate prophylactic agent used in Rizgary Teaching Hospital was only $1.3 \%{ }^{28}$ whereas in India, it was $68 \%{ }^{29}$, Iran $5.9 \%{ }^{30}$, Jordan $1.7 \%^{31}$ and Turkey $68 \%{ }^{32}$.

Escherichia coli were the commonest species isolated from the total cultures $(29.2 \%)$, this is in agreement with 20 studies of abdominal surgery and a rate of $20.3 \%{ }^{17}$. Another study in Saudi Arabia has shown that Escherichia coli was the most commonly isolated bacteria at a rate of $34.7 \%$. In addition, in China in 2010 reported that Escherichia coli had (25.9\%), Staphylococcus aureus (14.3\%), and P. aureuginosa (11.9\%) and that these three organisms were the most common pathogens associated with PSSIs ${ }^{19}$. In contrast, a study conducted in India has reported that the most predominant isolate was Staphylococcus aureus (37\%) of which $21.7 \%$ were MRSA. The possible cause for this difference is the smaller number of operations in the Indian study ${ }^{29}$. Moreover, a study in Saudi Arabia has reported $S$. aureus as the commonest isolate, and more than one third were MRSA ${ }^{34}$.

This difference in types of isolated bacteria depends on the operative site. E. coli and anaerobic organisms are frequent isolates following colorectal operations. However, exogenous sources are less frequently implicated and include surgical personnel, the operation room environment, and surgical instrument ${ }^{36}$.

The best means of preventing PSSIs is the perioperative administration of systemic antimicrobials ${ }^{27}$. This is indicated if the risk of PSSIs is greater than that of a clean-contaminated procedure. However, there is evidence that clean procedures can benefit from antimicrobial prophylaxis ${ }^{35,36}$.

Staphylococcus aureus still possess the high resistance to the commonly used antimicrobials in clinical practice. The average resistance rate of this species to Oxacillin was $(60 \%)$ and to Vancomycin, (60\%).This is a relatively higher percentage compared to a study by Reynolds R, et $a l$. in which the resistance to Oxacillin was $(42 \%)^{27}$.

The high resistance of E. coli to Livofloxacin, Cefazolin, Ceftriaxone, Cefepim, Ceftazidime, Aztreonam demonstrates how the high usage of those antibiotics reflects the existence of ES $\beta \mathrm{L}$ among the isolates, and this is similar to pattern of resistance that was observed for $K$. Pneumonia with multiple antibiotic resistance. There was a less resistant pattern for $P s$. aeruginosa. Meropenem, Imepenim, Ertapenem, and Amikacin were the most potent antibiotics which have high rate of sensitivity to all isolated organisms except for Acinobacter baumanni.

\section{REFERENCES}

1. Anderson DJ. Epidemiology of surgical site infection in adults (2015). https://www.uptodate.com/contents/epidemiolog y-of-surgical-site-infection-in-adults.

2. Awad, SS. "Adherence to surgical care improvement project measures and postoperative surgical site infections". Surgical Infection (Larchmt) (2012). 13(4): 234-7.

3. Kirby JP and Mazuski JE. Prevention of surgical site infection Surg Clin North Am (2009); 89: 36589 viii. doi: 10.1016/j.suc.2009.01.001. https://www.ncbi.nlm.nih.gov/pubmed/1928188 9.

4. Keping C, Jiawei L, Qingfang W, Nanyuan Y and Gohua X. Risk factors for surgical site infection in a teaching hospital: a prospective study of 1,138 patients. Patient Preference and Adherence (2015). 9: 1171-77.

5. Cantlon CA, Stemper ME. Schwan WR, Hoffman MA, Qutaishat SS. Significant pathogens isolated from surgical site infections at a community hospital in the Midwest. Am J Infect Control 2006; 34: 526 -29. 
6. Wong ES. Surgical site infection. In: Mayhall CG, editor. Hospital Epidemiology and Infection Control. Philadelphia: Lippincott Williams \& Wilkins; 2004. p. 287-310.

7. Therapeutic Guidelines: Antibiotic. Version 12. Melbourne: Therapeutic Guidelines Limited; 2003, 26:135.

8. Woodman N. World Health Organization Surgical Safety Checklist. ATOTW 325 (2016).https://www.aagbi.org/sites/default/files/ $325 \% 20$ WHO $\% 20$ Surgical $\% 20$ Safety $\% 20$ Checklist.pdf.

9. Humphreys H. Preventing surgical site infection. Where now? J Hosp Infect 2009; 73: 316-322.

10. Gottrup F, Melling A and Hollander D A. World Wide Wounds: An overview of surgical site infections: aetiology, incidence and risk factors. (2005).

http://www.worldwidewounds.com/2005/septem ber/Gottrup/Surgical-Site-Infections-

Overview.html

11. Shashidhar V, Kiran C and Anusha G. Multidrug resistant Gram-negative bacilli in lower respiratory tract infections.Iran $\mathrm{J}$ Microbiol. 2013; 5(4): 323-27.

12. Ahmed HJ, Nabeel A, Tharwat IS. The Effect of Perioperative use of Prophylactic Antibiotic on Surgical Wound Infection. Iraqi Postgraduate Medi. Jour. 2013: 12; 2.

13. Seyd MR, Mohammad I, Ahmad SK. and Ali J. Abdominal surgical site infections: incidence and risk factors at an Iranian teaching hospital. BMC Surg 2005, 5:2.

14. Gamal AK, Abdelmageed MK, Abdullah AA, Muhammed YA, Ahmed MZ, Muhammed YA, et al. Surgical Site Infection in a Teaching Hospital: A Prospective Study.Journal of Taibah university medical science.2011; 6(2):114-20

15. Bevin C, Yoon JC, Sandra HR, Yoko F, Matthew $\mathrm{N}$, Elaine L. Gender Differences in Risk of Bloodstream and Surgical Site Infection. J Gen Intern Med 2013; 28(10):1318-25

16. Soad H, Tamer S, Elham H, Manal E, Emam A, Laurel L, et al. Incidence and modifiable risk factor of surveillance of surgical site infection in Egypt: A prospective study. American Jour. Of infection control 2012: 40; 426-30

17. Allegranzi B, Bagheri NS, Combescure C, Graafmans W, Attar H, Donaldson L, et al. Burden of endemic health-care-associated infection in developing countries: systematic review and meta-analysis. Lancet 2011: $15 ; 377: 228-41$
18. Harihara Y. Konishi T. Surgical site infection (SSI) surveillance. Nihon Geka Gakkai Zasshi. 2006;107 (5):230-4.

19. Yunzhou F. Zhaoxia W. Weiwei W. Li T. Hongbo J. Lihong T. Yuguang C. et al. The Incidence and Distribution of Surgical Site Infection in Mainland China: A Meta-Analysis of 84 Prospective Observational Studies. Sci Rep. 2014; 4: 6783.

20. Koigi-Kamau R, Kabare LW, Wanyoike-Gichuhi J. Incidence of Wound Infection after Caeserean Delivery in a Distinct Hospital in central Kenya. East Afr Med J. 2005; 82(7):357-61

21. Muhemmad SA, Farkhanda JD, Ahsan AL, Faisal B, Noor MK. Journal of surgery Pakistan (International). 2011;16(1): 33-7.

22. Culver DH, Horan TC, Gaynes RP, Martone WJ, Jarvis WR, Emori TG, et al. Surgical wound infection rates by wound class, operative procedure, and patient risk index. National Nosocomial Infections Surveillance System.Am J Med 91, 152S - 78 (1991).

23. Kaye KS, Schmader KE. \& Sawyer R. Surgical site infection in the elderly population. Clin Infect Dis 39, 1835-41 (2004).

24. Haley RW, Culver DH, Morgan WM, White JW, Emori TG, Hooton TM. Identifying patients at high risk of surgical wound infection. A simple multivariate index of patient susceptibility and wound contamination. Am J Epidemiol 1985; 121: 206-15.

25. Tsai PS. Hsu CS. Fan YC. \& Huang CJ. General anaesthesia is associated with increased risk of surgical site infection after Caesarean delivery compared with neuraxial anaesthesia: a population-based study. Br J Anaesth 2011; 107 : 757-61

26. Pear SM. Relationship of Perioperative Hyperglycemia and Major Infections in Cardiac Surgery Patients. University of Arizona; 2004.

27. Reynolds R, Potz N, Colman M, Williams A, Livermore D, MacGowan A. Antimicrobial susceptibility of the pathogens of bacteraemia in the UK and Ireland 2001- 2002: the BSAC Bacteraemia Resistance Surveillance Programme. J. Antimicrob.Chemother. 2004; 1: 3- 12.

28. Ali AA, and Mazin AH. How Good is Compliance with Surgical Antibiotic Prophylaxis Guidelines in Erbil/ Iraq. 2nd International Conference on Medical, Biological and Pharmaceutical Sciences (ICMBPS'2013). London (UK) 2013.

29. Parulekar L, Soman R, Singhal T, Rodrigues C, Dastur FD, Mehta A. How good is compliance 
with surgical antibiotic prophylaxis guidelines in a tertiary care private hospital in India? A prospective study. Indian J Surg 2009; 71:15-8.

30. 48. Askarian $M$, Moravveji AR, Mirkhani $H$, Namazi S, Weed H. Adherence to American Society of Health-System Pharmacists surgical antibiotic prophylaxis guidelines in Iran. Infect Control Hosp Epidemiol 2006; 27:876-8. 54

31. Al-Momany NH, Al-Bakri AG, Makahleh ZM, Wazaify MMB. Adherence to international antimicrobial prophylaxis guidelines in cardiac surgery: a Jordanian study demonstrates need for quality improvement. . J Managed Care Pharmacy JMCP 2009; 15 (3): 262-71.

32. Hosoglu S, Sunbul M, Erol S, Altindis M, Caylan $\mathrm{R}$, Demirdag $\mathrm{K}$ et al. A national survey of surgical antibiotic prophylaxis in Turkey. Infect Control Hosp Epidemiol 2003; 24:758-61.

33. Leaper DJ. Risk factors for and epidemiology of surgical site infections. Surg Infect (Larchmt). 2010; 11(3): 283-7.

34. Al-Ali KY. Evaluation of surveillance for surgical site infections and Drug Susceptibility patterns, Taif, saudi Arabia annals of clinical and lab. reaearch.2016;4:78

35. Antibiotic prophylaxis in surgery a national guideline.SIGN.2008:104. www. sign. ac.uk

36. Shankar VG. Srinivasan K. Sistla SC. jagdish S. Prophylactic Antibiotic in open mesh repair of inguinal hernia- A randomized control trial.International journal of surgery. 2010, 8:4

ئامانج لهم تويّزينهوهيه زانينى زمارهى ئهو نهخوّشانهى كه له دواى نهشتهرگهرى توشى ههوكردنى برينى

نه شتهرگهرى دهبن ههروهها دوّزينهوهى ئهو مه ترسيانهى دهبنه هوّكارى دروسبوونى نهخوّشيه كه, بوّ ئهو نهخوّشانهى له نه خوّشخانهى رزكارى فيّركارى /ههولِيّر دهخويّنريّت, ههروهها زانين و ناسينهوهى جوّكارهكانى بهكتريا و يشكنينى دزه

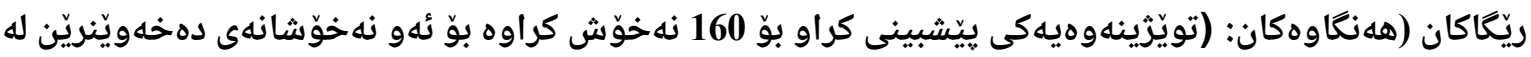

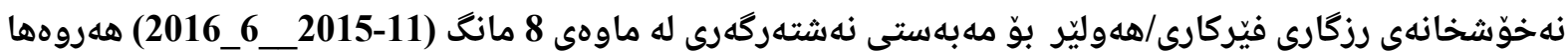

زانين و ناسينهوهى جوّكارهكانى به كتريا و يشكنينى دره ميكروّب له ريكه بو به كارهينان.VITEK2 COMPACT ئهنجام:

• ريّزهى تووشبوانى ههوكردنى برينى نهشتهرگهرى بريتى بوو له E.coli 19 يه كيّك بوو له زوّرترين ئهو بهكتريايانهى

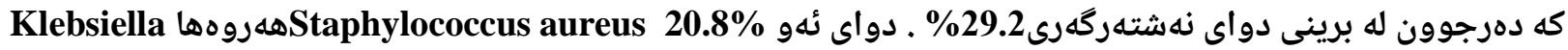
ريّزّهيان بريتى بوو له 12.5peumonia and Coagulase negative staphylococci

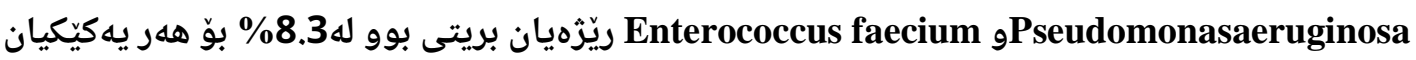

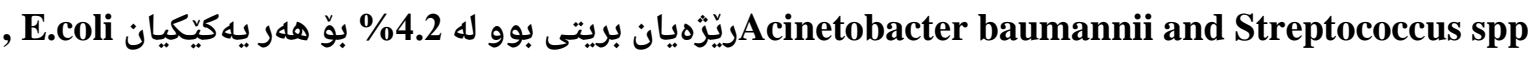

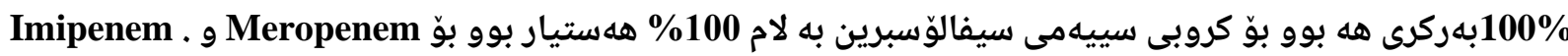
ئهو هوّكارانهى له يشت توشبونى ههوكردنى برينن بريتى بوون له جكهره كيّشان, هلبوونى نهخوّشى دريّزخايهن, برينى نه شتهرگهرى ييس, زوّرى ماوهى نه شتهرگهرى,ههروهها خراب بهكارهيّنانى دزه به كتريا. دهئه نجام:

ليرهدا دهركهوت كه جهندين بكتريا ههن كه تواناى بهرگريان بوّ دزه بكتريا زوّر به هيّه وهك E.coli : و Staphylococcus aureus ههروهها جه ندين هوّكار ههن بوّ يهيدابوونى وهك خراي به كارهيّنانى دزه به كتريا يِيش و دواى نهشتهرگهرى. 
انواع البكتريا والعوامل المسببه للأ لتهابات المكتسبة بعد العمليات الجراحيه ومدى استجابتها للمضادات الحيوية في مستشفى رزكاري التعليمي في مدينة اربيل - العراق.

الأهداف :

لايجاد نسب الألتهابات المكتسبة بعد العمليات الجراحيه في مستشفى رزكاري التعليمي والتعرف على البكتريا المسببه ومدى استجابتها للمضادات الحيوية لها.

الطريقة:

تمت الدراسة على 160 مريض راقد في مستشفى رزكاري خلال 8 أشهر من تشرين الثاني 2015 ولغاية حزيران

2016 وتم عزل البكتريا وزرعها وتشخيصهاوكدلك معرفة نسبة مقاومتها للمضادات الحيوية البكتريا المسببه لها ونسب مقاومتها للمضادات الحيوية. النتائج:

نسبة الاصابه بالإلتهابات الجراحية هي 19.4\% 20.8 aureus المخاطر الملازمة للاصابة كان Pseudomonas aeruginosa و 8.3 Enterococcus faecium لكل ونهما و و Acinetobacter baumannii E.coli من Staphylococcus aureus كانت مقاومة للأوكساسيلين , فكانت : التدخين, الامراض المزمنة, مدة العمليات الجراحية وسوء استخدام المضادات الحيوية. الاستنتاج: هناك بكتريا لا تستجيب لمعظم المضادات الحيوية وخاصة Staphylococcus aureus وكذلك E.coli وذلك لسوء استخدام المضادات الحيويه ولقلة الارشادات في استخدام المضادات الحيوية قبل العمليات وبعدها. 